\title{
Noise Levels and Frequency Response from Religious Houses in Portharcourt City Local Government Area
}

\author{
Ononugbo Chinyere Philomina ${ }^{1, *}$, Avwiri Eseroghene ${ }^{2}$ \\ ${ }^{1}$ Department of Physics, University of Port Harcourt, Port Harcourt, Nigeria \\ ${ }^{2}$ Department of Curriculum Studies and Educational Technology, University of Port Harcourt, Port Harcourt, Nigeria
}

Email address:

onochinyere@yahoo.co.uk (O.C. Philomina)

${ }^{*}$ Corresponding author

\section{To cite this article:}

Ononugbo Chinyere Philomina, Avwiri Eseroghene. Noise Levels and Frequency Response from Religious Houses in Portharcourt City Local Government Area. International Journal of Environmental Protection and Policy. Vol. 7, No. 1, 2019, pp. 24-31. doi: 10.11648/j.ijepp.20190701.14

Received: January 15, 2019; Accepted: February 25, 2019; Published: March 16, 2019

\begin{abstract}
Introduction: Noise pollution in churches is one of the health challenges facing developing nations of the world. Both Pastors/Reverends are exposed to different sound levels during church services, many of which can last for hours. According to the Nigerian National Environmental standard and regulation Act 2007, the maximum permissible noise level in worship centers should not exceed $75 \mathrm{~dB}$ and Nigeria being the highest church proliferation in the world makes it imperative to carry out this research. Aim: the aim of this study is the measure the equivalent noise levels with their corresponding frequency levels at varying distances from the source and quantify the noise pollution levels in churches and mosques in Port Harcourt. Method: a total of 11 Pentecostal churches, 5 orthodox churches and 3 central mosques were randomly selected. This study was carried out between July and August, 2017. Sound pressure level meter was used to measure the sound levels under the weighted range in churches on Sundays between the hours of 7.30 to $12.0 \mathrm{pm}$ and on Fridays in mosques between the hours of 1.30 to $3.00 \mathrm{pm}$ afternoon session and evening at $6.00 \mathrm{pm}$. Data obtained was analyzed using ms-excel. Result: Average indoor and outdoor equivalent noise level in pentecostal churches are $95.1 \mathrm{~dB}(\mathrm{~A})$ and $79.5 \mathrm{~dB}(\mathrm{~A})$ respectively while that for orthodox churches are $93.6 \mathrm{~dB}(\mathrm{~A})$ and $77.9 \mathrm{~dB}(\mathrm{~A})$ respectively. The average indoor and outdoor equivalent noise levels in mosques are 72.1 and $100.6 \mathrm{~dB}(\mathrm{~A})$. The frequency of the noise ranges from 310.75 to $785.30 \mathrm{~Hz}$ in Pentecostal, 482.60 to $749.02 \mathrm{~Hz}$ in Orthodox churches and 438.63 to $620.36 \mathrm{~Hz}$ in mosques. The highest noise pollution level in churches and mosques recorded are $121.18,119.38$ and $123.48 \mathrm{~dB}$ for pentecostal, orthodox and mosques respectively. Conclusion: all the noise pollution levels recorded in the churches and mosques are higher than the safe permissible limits of sound of $75 \mathrm{~dB}$ thus making it unhealthy, unsafe for the worshippers. Therefore there is need for implementation of the noise regulation laws in churches in Nigeria in order to reduce the risk of hearing loss.
\end{abstract}

Keywords: Noise Pollution, Equivalent Noise, Mosque, Pentecostal

\section{Introduction}

Noise which is an unwanted sound that disrupts human activities has been a major concern in many of the built environments. Noise pollution is an unwanted or undesirable sound in peripheral environment. In other words, it is indefinite and irregular combination of sounds [1]. Noise pollution has many effects on humans, including hearing loss, emotion effects (feeling of physical discomfort in ears), impaired communication, psychosomatic effects on physical well-being, and inappropriate effects on the psychological states of people [2]. Much noise can also leave adverse effects on work efficiency and events. It can also cause impaired sleep and behavior, increased gastric intestinal activity, heart rate, blood pressure, respiratory rate, and oxygen consumption $[3,4]$. One of the places where high levels of noise can have a significant effect on public health is churches and mosques. Chad Kitundu [5], reported that Rwanda government shuts down 700 churches for noise pollution. The first important phase to control noise pollution that is very important nowadays is to measure noise pressure 
level and the considered parameters and to compare it with standard parameters $[6,7]$.

Churches and mosques represent an excellent environment in the propagation of sound which poses a high risk in the occurrence of noise induced hearing loss [8]. Many of them have increased their musical experience with loud music instruments, and some of them are always filled with thousands of people during their weekend service with loud blaring music from musical instruments. A great percentage of the population in this region are ignorant of the effects of being expose to high noise level. The World Health Organization estimates that about 1.1 billion children and youth around the world may face the risk of hearing loss and other harmful effects due to unsafe listening practices [9]. Chronic exposure to moderate sound levels of less than 90 $\mathrm{dB}$ as found in many church environment causes the hair cells especially the outer hair cells of the inner ear to degenerate within the organ of corti during each period of exposure [8]. Safe permissible sound levels to hearing, depend on the intensity (loudness) and duration of exposure [10]. The longer the exposure and the more intense the sound, the more the degeneration and loss of hair cells [11].

The global society today is undergoing significant constant proliferation of religious houses which are thought to provide solutions to the numerous problems confronting people, especially, the black race and Nigeria in particular [12]. Nigeria is a country with the highest number of churches per capital in the world and a fertile soil for the growth of independent churches [13]. This proliferation of religious houses is borne out of the understanding that in Nigeria, there is freedom of religious worship but central to this is the question of its environmental effects on the people in the society [12]. Religious houses are springing up at an alarming rate in all available spaces, shops, uncompleted buildings, warehouses, hotels, abandoned cinema buildings, studios and other public places. It is a common sight to see a minimum of fifty different religious centers on a street of four kilometers long [13].

Churches and places of worship represent an excellent sound propagation in a closed space which poses a high risk in the occurrence of noise induced hearing loss [14]. They have several sources of sound which includes piano, organs, bands, choir and the loud speakers [15]. The hazardous effect of sound in places of worship can be reduced by attaching "special sound limiters" to the sound systems [15]. These are devices that automatically limit the output volume or the intensity of sound produced from the systems, thereby reducing the resultant sound effect.

Noise exposure prediction models that are used in health effect studies normally yield free field exposure levels outside residences as results. In these models, the sound insulation of buildings is neglected. However, to assess the sound exposure of the inhabitants inside buildings, an estimate of the indoor sound level is necessary, as people spend a considerable amount of their time indoors [16]. According to Nigerian National environmental noise standard and regulation Act established in 2007 and enacted to view on the minimum health and safety requirement regarding the exposure risk arising from noise, the maximum permissible noise level in worship centers should not exceed $75 \mathrm{~dB}$. Considering the fact that Nigeria have the highest rate of church proliferation in the world, makes it imperative to carry out this research work. The aim of this study is to measure the equivalent noise level with their corresponding frequencies and determine the noise pollution level in order to quantify the exposure level of church worshippers in Port Harcourt.

\section{Materials and Methods}

\subsection{Study Area}

Port Harcourt Local Government Area (PHALGA) is a local government area of Rivers State in southern Nigeria. It is one of the 23 local government areas created for the state. Its administrative head quarter is located at Moscow Road. Port Harcourt local government area is included in the Greater Port Harcourt region. It is situated 52 kilometres southeast of Ahoada and about 40 kilometre northwest of Bori. It is bounded to the south by Okrika, to the east by Eleme, to the north by Obio-Akpor and to the west by Degema. It has a total size of 109 square kilometres. The total population in the area was last recorded at 638,360 people in 2011. It has many educational institution and religious houses. Port Harcourt Local Government Area is located on latitude $4^{\circ} 48^{\prime} 55.994^{\prime \prime} \mathrm{N}$ and on longitude $7^{\circ} 2^{\prime}$ 59.438"E (Wikipedia).

\subsection{Method}

Noise level measurement was carried out in 3 religious houses namely, the Mosques, Orthodox churches and Pentecostal churches. 11 Pentecostal churches, 5 Orthodox churches and 3 mosques were selected for this work all in Port Harcourt city Local Area, Rivers State Nigeria. Noise level was measured in July and August 2017. The sound level meter was calibrated before taking measurements in the calibration procedure, the meter was switch to A-weighting slow response and $50-100 \mathrm{~dB}$. The sound meter is a tool created for noise project, quality control, inaccuracy prevention and for all kinds of environmental sound effects. The activities in the area where this churches and Mosque are located include: business centres, residential buildings and schools.

Noise level was measured in Pentecostal churches on Sundays in the morning hours and in the afternoon, morning measurement was done from 7:30am to 12:00 noon while the afternoon measurement was taken from $12: 30 \mathrm{pm}$ to $3: 30 \mathrm{pm}$. The sound level meter was hand held and well positioned with the wind shield on and was held 3 meters from the noise source. Noise level Measurement was taken for a period of $1 \mathrm{hr}$ for each church location, the measurement was taken interiorly and exteriorly. The interior measurement was done during worship, praise and offertory time while exterior measurement was taken during preaching time. 
Also measurement was done at some distances away from the church. The process was carried out for 11 Pentecostal churches. For the orthodox churches, noise level measurement was taken on Saturdays and Sundays in the morning, afternoon and evening. The morning reading was carried out from 10:30 am to 12:00 noon, afternoon measurement started from $12: 30 \mathrm{pm}$ to $3: 00 \mathrm{pm}$ while the evening measurement was done from 4:00 pm to 6:00 pm. The reading was taken interiorly and exteriorly. The interior reading was carried out during and offertory time while the exterior reading was done during time for sermon noise level measurement was also taken at some distances away from the church. This procedure was carried out for 5 Orthodox churches and in each case the sound level meter was held at 3 meters away from the noise source.

Noise measurement in the mosques was done on Fridays, afternoon and evening. The afternoon measurement was carried out from 1:30 pm to $3: 00 \mathrm{pm}$ and evening measurement was done from 4:00 pm to $6: 00 \mathrm{pm}$. The reading was done interiorly and exteriorly, the interior reading was taken during recitation of the Quran and exterior reading was done during the mosques call to prayer and the noise level was taken directly from the loudspeaker mounted on the mosques building.

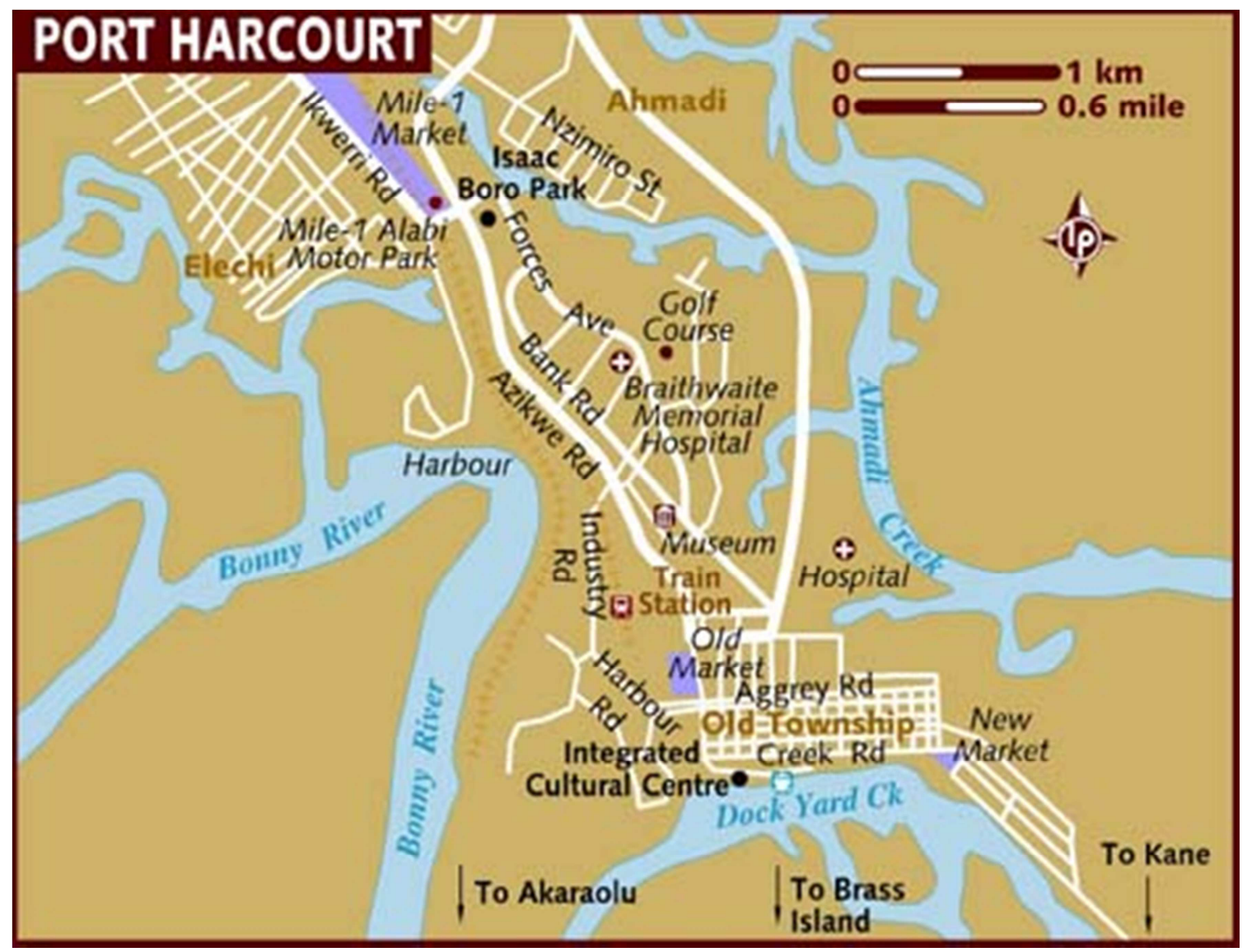

Figure 1. Map of Rivers State showing the study Area.

\section{Results}

\subsection{Equivalent Noise Levels in Churches and Mosque}

Table 1 presents the results of noise levels measured at Pentecostal churches, Orthodox churches and Mosques. Tables
1, 2 and 3 shows the equivalent noise levels obtained from the Pentecostal churches, Orthodox churches and Mosques. In Table 4, 5, 6 while the mosque has the lowest of $72.10 \mathrm{~dB}(\mathrm{~A})$. The table also shows that the Mosque has the highest exterior noise level of $100.60 \mathrm{~dB}(\mathrm{~A})$ while the Orthodox churches has the lowest exterior noise of $77.90 \mathrm{~dB}(\mathrm{~A})$.

Table 1. Equivalent noise levels and Frequency distribution in Pentecostal churches.

\begin{tabular}{|c|c|c|c|c|c|c|c|c|}
\hline $\mathbf{S} / \mathbf{n}$ & Name of churches & Location & $\begin{array}{l}\text { Interior noise } \\
\text { level } \mathrm{dB}(\mathrm{A})\end{array}$ & $\begin{array}{l}\text { Exterior noise } \\
\text { level } \mathrm{dB}(\mathrm{A})\end{array}$ & $\begin{array}{l}10 \mathrm{~m} \\
\mathrm{~dB}(\mathrm{~A})\end{array}$ & $\begin{array}{l}20 m \\
d B(A)\end{array}$ & $\begin{array}{l}40 \mathrm{~m} \\
\mathrm{~dB}(\mathrm{~A})\end{array}$ & $\begin{array}{l}\text { Frequency } \\
(\mathrm{Hz})\end{array}$ \\
\hline 1 & Salvation ministries & Okija str.mile1 & 96.50 & 78.2 & 63.4 & 55.2 & no data & 580.03 \\
\hline 2 & Assemblies of God Church & Aggrey road & 102.20 & 80.2 & 75.5 & 60.4 & 56.5 & 580.75 \\
\hline 3 & Living Faith Church & Kaduna str. $\mathrm{d} /$ line & 95.20 & 75.5 & 65.5 & 52.5 & 45.1 & 785.30 \\
\hline 4 & Deeper Life Bible Church & Urualla str.mile1 & 92.20 & 84.3 & 70.2 & 68.5 & No data & 580.03 \\
\hline 5 & $\begin{array}{l}\text { Greater Evangelism world crusade } \\
\text { church }\end{array}$ & Lagos bus stop road & 100.20 & 82.5 & 66.2 & 60.5 & 40.1 & 540.24 \\
\hline
\end{tabular}




\begin{tabular}{|c|c|c|c|c|c|c|c|c|}
\hline $\mathbf{S} / \mathbf{n}$ & Name of churches & Location & $\begin{array}{l}\text { Interior noise } \\
\text { level } \mathrm{dB}(\mathrm{A})\end{array}$ & $\begin{array}{l}\text { Exterior noise } \\
\text { level } \mathrm{dB}(\mathrm{A})\end{array}$ & $\begin{array}{l}10 m \\
d B(A)\end{array}$ & $\begin{array}{l}20 \mathrm{~m} \\
\mathrm{~dB}(\mathrm{~A})\end{array}$ & $\begin{array}{l}40 \mathrm{~m} \\
\mathrm{~dB}(\mathrm{~A})\end{array}$ & $\begin{array}{l}\text { Frequency } \\
(\mathrm{Hz})\end{array}$ \\
\hline 6 & Christ Embassy Church & mile 1 Diobu & 89.30 & 75.8 & 68.5 & 65.1 & No data & 480.53 \\
\hline 7 & Redeemed Christian church of God & Lagos bus top & 96.40 & 87.3 & 75.5 & 65.1 & No data & 643.02 \\
\hline 8 & The kings assembly & 1 stadium road & 86.5 & 65.5 & 55.2 & No data & No data & 451.24 \\
\hline 9 & Mountain of Fire and Miracle Ministry & 92 urualla str.mile1 & 98.6 & 88.5 & 75.3 & 50.5 & No data & 654.48 \\
\hline 10 & Mount Zion light house ministry & 12. urualla str.mile 1 & 100.7 & 81.3 & 72.3 & 56.3 & No data & 310.75 \\
\hline \multirow[t]{2}{*}{11} & united believers evangelical church & 14 urualla str.mile 1 & 88.3 & 75.3 & 65.3 & 53.4 & No data & 423.10 \\
\hline & Averages & & 95.1 & 79.5 & 68.5 & 55.97 & 18.56 & 520.86 \\
\hline
\end{tabular}

Table 2. Equivalent Noise Level and Frequency Recorded From Orthodox Churches.

\begin{tabular}{|c|c|c|c|c|c|c|c|c|}
\hline $\mathbf{S} / \mathbf{n}$ & Name of church & location & $\begin{array}{l}\text { Interior noise } \\
\text { levels } \mathrm{dB}(\mathrm{A})\end{array}$ & $\begin{array}{l}\text { Exterior noise } \\
\text { levels } \mathrm{dB}(\mathrm{A})\end{array}$ & $10 \mathrm{~m} \mathrm{~dB}(\mathrm{~A})$ & $\begin{array}{l}20 \mathrm{~m} \\
\mathrm{~dB}(\mathrm{~A})\end{array}$ & $\begin{array}{l}40 \mathrm{~m} \\
\mathrm{~dB}(\mathrm{~A})\end{array}$ & $\begin{array}{l}\text { Frequency } \\
(\mathrm{Hz})\end{array}$ \\
\hline 1 & St. Marys catholic church & Lagos bus stop & 94.5 & 82.2 & 70.5 & 68.5 & No data & 482.60 \\
\hline 2 & Cherubim and Seraphim & Aggrey road & 100.4 & 80.3 & 65.1 & 58.3 & 50.44 & 749.02 \\
\hline 3 & Seventh day Adventist & Aggrey road & 85.4 & 72.4 & 60.3 & 68.3 & 58.23 & 483.31 \\
\hline 4 & St. Pauls Anglican church & Lagos bus stop & 92.3 & 76.3 & 63.3 & 50.2 & No data & 526.02 \\
\hline \multirow[t]{2}{*}{5} & Brotherhood of the cross and stars & Aggrey road & 95.4 & 75.2 & 72.1 & 58.3 & No data & 680.04 \\
\hline & Averages & & 93.6 & 77.9 & 66.3 & 60.7 & 21.73 & 584.20 \\
\hline
\end{tabular}

Table 3. Equivalent Noise Level and frequency responses Obtained From Mosques.

\begin{tabular}{|c|c|c|c|c|c|c|c|c|}
\hline $\mathbf{s} / \mathbf{n}$ & Name of mosques & location & $\begin{array}{l}\text { Interior noise } \\
\text { levels } \mathrm{dB}(\mathrm{A}) \\
\end{array}$ & $\begin{array}{l}\text { Exterior noise } \\
\text { levels } \mathrm{dB}(\mathrm{A})\end{array}$ & $10 \mathrm{~m} \mathrm{~dB}(\mathrm{~A})$ & $20 \mathrm{~m} \mathrm{~dB}(\mathrm{~A})$ & $40 \mathrm{~m} \mathrm{~dB}(\mathrm{~A})$ & $\begin{array}{l}\text { Frequency } \\
(\mathrm{Hz})\end{array}$ \\
\hline 1 & Mile1 central mosques & Mile 1 & 75.2 & 104.5 & 98.3 & 72.3 & 65.4 & 620.36 \\
\hline 2 & Borokiri mosques & 38 Bonny str. Borokiri & 72.4 & 96.9 & 76.5 & 65.1 & 56.8 & 438.63 \\
\hline \multirow[t]{2}{*}{3} & Mille 3 mosques & Mile 3 & 68.8 & 100.4 & 75.8 & 72.2 & 58.1 & 560.31 \\
\hline & Averages & & 72.1 & 100.6 & 83.5 & 69.9 & 59.9 & 539.77 \\
\hline
\end{tabular}
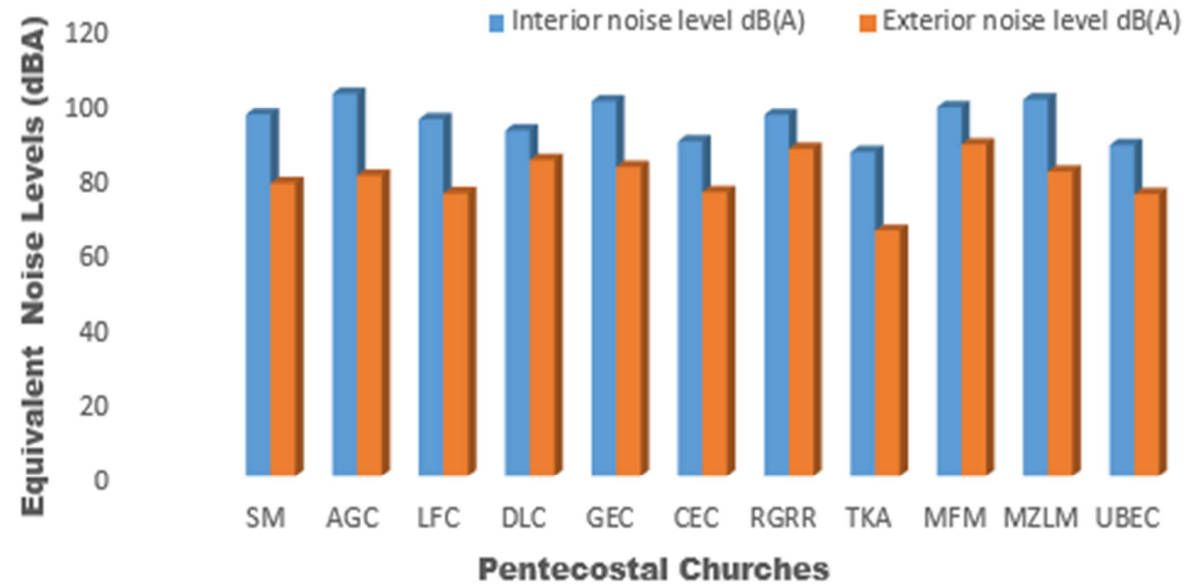

Figure 2. Interior and exterior noise levels in Pentecostal churches.
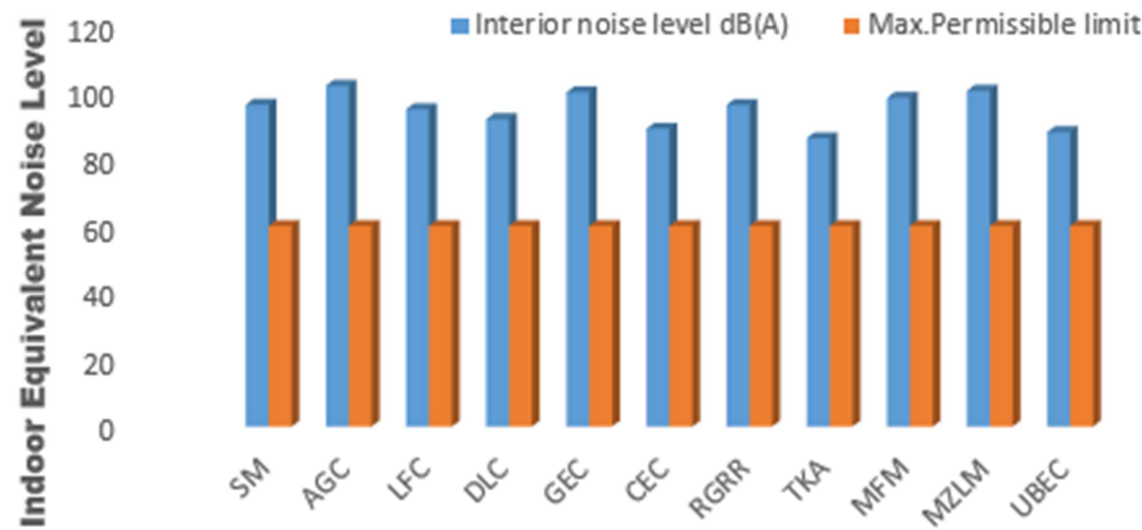

Pentecostal Churches

Figure 3. Interior noise levels in Pentecostal Churches with max. Permissible limit [15]. 

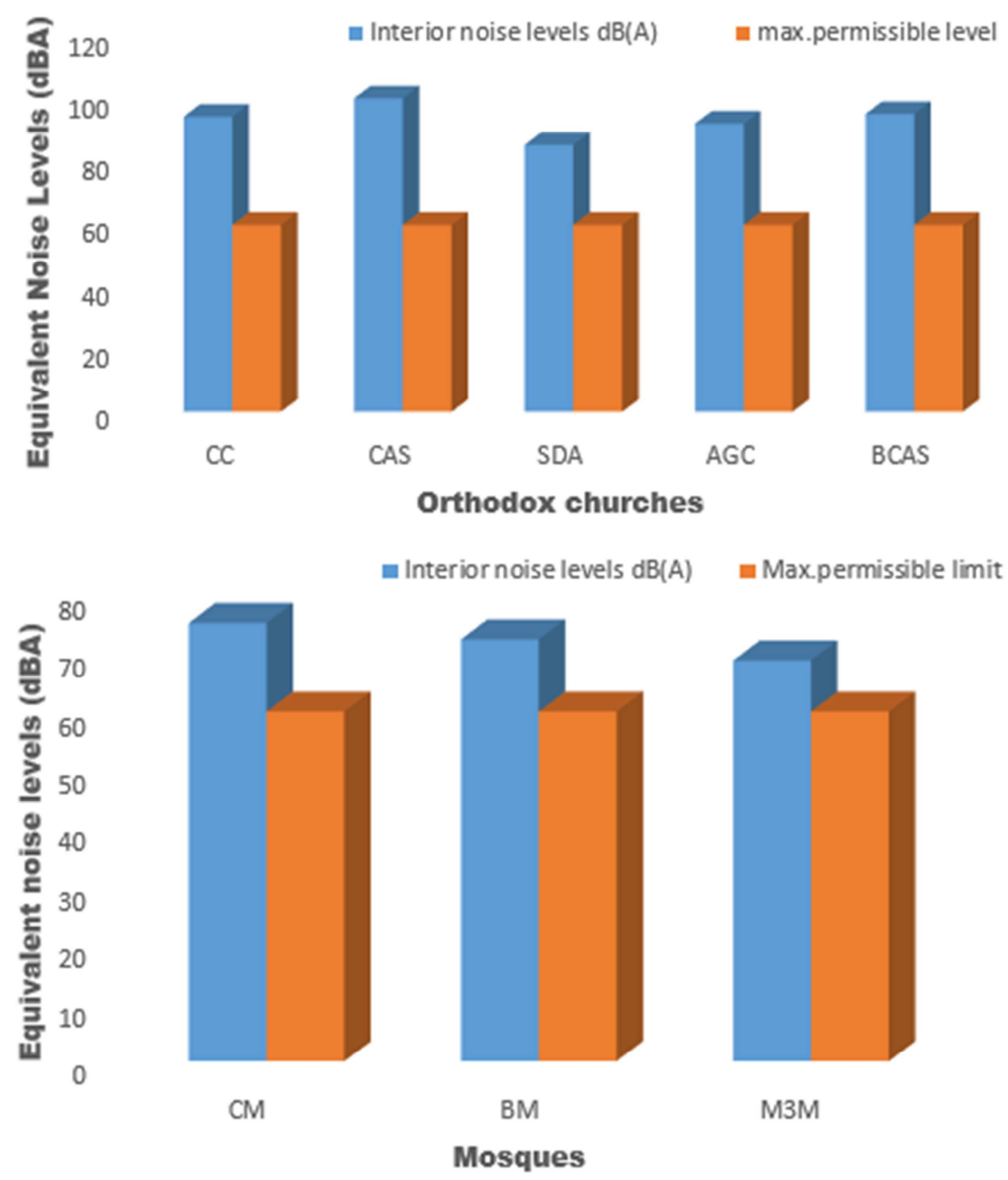

Figure 4. Interior noise level in Orthodox churches with maximum Permissible Limits [15].

\subsection{Noise Pollution Level}

Based on statistics, assessment of noise influence on an individual depends on the level that equates the equivalent continuous noise level (Leq) and the noise pollution level (Lnp). The noise pollution level can be calculated using the relation by (ISO/SR131-1959) [17]:

$$
\mathrm{Lnp}=\mathrm{Leq}+\mathrm{k} \sigma
$$

Where $\mathrm{k}$ is a constant with a value of 2.565 and $\sigma$ is the standard deviation with value $=7.4 \mathrm{~dB}$ for A- weighted level in ranking for which a variety of common noise are involved for their loudness [18].

Table 4. Noise Pollution Levels in Pentecostal churches.

\begin{tabular}{|c|c|c|c|c|c|}
\hline \multirow{2}{*}{$\mathbf{S} / \mathbf{N}$} & \multirow{2}{*}{ Name of Churches } & \multicolumn{2}{|l|}{ Interior } & \multicolumn{2}{|l|}{ Exterior } \\
\hline & & LEQ dB(A) & $\operatorname{Lnp}(\mathrm{dB})$ & LEQ dB(A) & $\operatorname{Lnp}(\mathrm{dB})$ \\
\hline 1 & Salvation ministries & 96.5 & 115.48 & 78.2 & 97.20 \\
\hline 2 & Assemblies of God Church & 102.2 & 121.18 & 80.2 & 99.18 \\
\hline 3 & Foundation Faith Church & 95.2 & 114.18 & 75.5 & 94.48 \\
\hline 4 & Deeper Life Bible Church & 92.2 & 111.18 & 84.3 & 103.28 \\
\hline 5 & Greater Evangelism world crusade church & 100.2 & 119.18 & 82.5 & 101.48 \\
\hline 6 & Christ Embassy Church & 89.3 & 108.28 & 75.8 & 94.78 \\
\hline 7 & Redeemed Christian church of God & 96.4 & 115.38 & 87.3 & 106.28 \\
\hline 8 & the kings assembly & 86.5 & 105.48 & 65.5 & 84.48 \\
\hline 9 & Mountain of Fire and Miracle Ministry & 98.6 & 117.58 & 88.5 & 107.48 \\
\hline 10 & Mount Zion light house ministry & 100.7 & 119.68 & 81.3 & 100.28 \\
\hline 11 & United believers evangelical church & 88.3 & 107.281 & 75.3 & 94.28 \\
\hline
\end{tabular}


Table 5. Noise Pollution level for Orthodox churches.

\begin{tabular}{|c|c|c|c|c|c|}
\hline \multirow{2}{*}{$\mathbf{S} / \mathbf{n}$} & \multirow{2}{*}{ Name of churches } & \multicolumn{2}{|l|}{ Interior } & \multicolumn{2}{|l|}{ Exterior } \\
\hline & & noise levels (dB) & Lnp (dB) & noise levels (dB) & Lnp (dB) \\
\hline 1 & St. Marys catholic church & 94.5 & 113.48 & 82.2 & 99.23 \\
\hline 2 & Cherubim and saraphine & 100.4 & 119.38 & 100.4 & 99.30 \\
\hline 3 & Seventh day adventist & 85.4 & 104.39 & 85.4 & 91.38 \\
\hline 4 & St. pauls angelican church & 92.3 & 111.28 & 92.3 & 95.33 \\
\hline 5 & Brotherhood of the cross and stars & 95.4 & 114.28 & 95.4 & 94.21 \\
\hline
\end{tabular}

Table 6. Noise Pollution level (Lnp) for Mosques.

\begin{tabular}{lllll}
\hline \multirow{2}{*}{ S/N } & \multirow{2}{*}{ Name of mosques } & Interior & Exterior \\
\cline { 3 - 5 } & & noise level (dB) & Lnp (dB) & noise level (dB) \\
\hline 1 & Mile1 central mosques & 75.20 & 94.18 & 104.50 \\
2 & Borokiri mosques & 72.40 & 91.38 & 96.90 \\
3 & Mille 3 mosques & 68.80 & 87.80 & 100.40 \\
\hline
\end{tabular}

\section{Discussion}

Table 1-3 shows the indoor and outdoor noise levels and frequency responses in Pentecostal churches, orthodox churches and mosques respectively at different distances from the sources in Port Harcourt metropolis. In Table 1, the noise levels measured in all the Pentecostal churches were higher at lower distances from the sources than at higher distances. At $10 \mathrm{~m}$ away from the source, Assemblies of God church, Redeemed Christian church and Mountain of fire and miracles ministries recorded the highest equivalent noise level of $75.5 \mathrm{dBA}$ respectively while the Kings Assembly recorded the least. At a distance of $40 \mathrm{~m}$ away from the source only three Pentecostal churches recorded noise levels of 56.5, 45.1 and 40.1 dBA corresponding to Assemblies of God church, living Faith church and Greater Evangelism world crusade respectively as shown in figure 2. The frequency of the noise ranges from $310.75 \mathrm{~Hz}$ (Mount Zion light house ministry) to $785.30 \mathrm{~Hz}$ (Living Faith church) with an average frequency of $520.86 \mathrm{~Hz}$. Generally the interior equivalent noise levels measured in all the Pentecostal churches samples in this study were higher than their exterior noise levels and also higher than the maximum permissible noise level of $60 \mathrm{Dba}$ as shown in Figures 2 and 3 respectively.

In Table 2, five orthodox churches was studied. The indoor noise level measured ranges from 85.4 to $100.4 \mathrm{~dB}(\mathrm{~A})$ while the outdoor noise level ranges from 72.4 to $82.2 \mathrm{~dB}(\mathrm{~A})$ at 10 $\mathrm{m}$ away from the source, the highest noise level was recorded at Brotherhood of the cross and star while the lowest noise level was obtained at Seventh day Adventist. At $40 \mathrm{~m}$ away only cherubim and Seraphim and Seventh day Adventist recorded noise levels of 50.44 and $58.23 \mathrm{dBA}$ respectively as indicated in Figure 4. Figure 4 shows the comparison of equivalent noise levels in orthodox churches with maximum permissible limit of $60 \mathrm{dBA}$. The noise levels in orthodox churches were higher than the permissible value as shown in figure 4 . The frequency of the noise ranges from $482.60 \mathrm{~Hz}$ to $749.02 \mathrm{~Hz}$ with an average value of $584.2 \mathrm{~Hz}$.

The indoor noise levels recorded in Mosques as presented in Table 3 ranges from 68.8 to $75.2 \mathrm{dBA}$ with an average value of $72,1 \mathrm{dBA}$ while the outdoor noise level ranges from 96.9 to $104.5 \mathrm{dBA}$ with an average value of $100.6 \mathrm{dBA}$. At $10 \mathrm{~m}$ away from the source, mile 1 central mosque recorded the highest noise level of $98.3 \mathrm{dBA}$ and mile 3 mosque recorded the least value of $65.2 \mathrm{dBA}$. Unlike Pentecostal churches and orthodox churches, at 40 $\mathrm{m}$ away from the source, all the mosques studied recorded high noise level. This could be due to the type of loud speakers in mosque which is highly elevated that projects noise away to far distances. The highest frequency of the noise recorded in mosque was $620.36 \mathrm{~Hz}$ with an average value of $539.77 \mathrm{~Hz}$.

Figure 4 is a comparison of the average indoor and outdoor equivalent noise levels measured in Pentecostal church, Orthodox churches and Mosques with the National noise standard. it is evident the both indoor and outdoor equivalent noise exceeded the standard stipulated by NERD [19]. The outdoor equivalent noise in mosque exceeded the indoor noise level due to the type of loud speaker they use, which is highly elevated that noise can be heard at large distances.

Frequency weightings also known as frequency networks and frequency filters correlate measured sound pressure levels with the human assessment. The human ear is frequency selective. Between $500 \mathrm{~Hz}$ and $6000 \mathrm{~Hz}$, our ears are very sensitive compared to lower and higher frequencies. The full range for young people is 20 to $20,000 \mathrm{~Hz}$. From this analysis, the frequency of noise measured in this work are within the audible range which may not pose any health hazard to the members of the church who are exposed to the noise.

Table 4 shows the noise pollution levels in Pentecostal churches. The highest indoor and outdoor noise pollution levels recorded are $121.18 \mathrm{~dB}$ and $107.48 \mathrm{~dB}$ respectively. The noise pollution levels recorded in the Pentecostal churches exceeded the permissible safe levels of $75 \mathrm{~dB}$ [8]. Table 5 shows the noise pollution level of orthodox churches. Cherubim and Seraphim recorded the highest indoor and outdoor noise pollution level of $119.38 \mathrm{~dB}$ and $99.30 \mathrm{~dB}$ respectively while Seventh day Adventist recorded the least noise pollution levels of 104.39 and $91.38 \mathrm{~dB}$ respectively. All the orthodox churches studied recorded noise levels higher than the permissible safe level of $75 \mathrm{~dB}$. Table 6 presents the noise pollution levels 
of three mosques in Port Harcourt. All the central mosque studied recorded higher noise pollution levels than the safe value.

Most churches in Port Harcourt have different categories of sound systems which includes organ or piano, bands and microphone during preaching. The bands, organs and piano amplifies the sound which increases the intensity. This also increases the sound energy and exposure risk. The sound emanating from the sources of sound are further amplified by the loud speakers. The higher the number of loud speakers, the higher the sound energy generated. The number of speakers in each of the churches in this study ranges from 6 to 30 with the Pentecostal churches having the highest 9 to 30 . This shows a higher attendant risk of exposure in the Pentecostal churches compared to other denominations.

Speaker position is very critical when assessing the level of sound an individual is exposed to at ear level, the sound level an individual is exposed is highest when compared to the floor or at higher levels. All the churches in this study have their speakers at all levels (floor, ear and higher) making it higher in propensity to cause deleterious effect while mosques have their speaker at the higher levels. A purpose-built church considers the acoustics during the building planning stage. An acoustic building considers both primary and secondary reflections of sounds which is generated from the sources while confused sounds emanate from the buildings not acoustically planned which causes greater exposure risk [14].

It is observed that al the churches and mosques studied were purpose built but none of them was acoustically designed. This shows that there is a higher tendency in producing confused sounds which are of a higher sound exposure risk in all the churches. The presence of children among the worshippers also requires attention and caution because they show greater susceptibility to loud sounds (noise) [20]

This means that a large population is being exposed to sound hazards during church worships, hence there is need to introduce a sound preventive program in our churches.

\section{Conclusion}

A high indoor and outdoor equivalent noise level and noise pollution levels was reported in all the churches above the safety permissible limits of sound. The frequency of noise levels measured are within the audible range.

All the churches had long noise exposure time with the Pentecostal churches being the highest. Significantly, all the church buildings were not acoustically designed which increases the deleterious effect of the sound.

Following the observations made in this study, the following recommendations were made:

1. Sound limiters should be attached to sound systems in our churches to reduce the noise intensity.

2. The loud speakers should be positioned high and away from the worshippers to reduce the effect on the ear.
3. Churches and mosques should be acoustically designed to reduce the resultant sound energy produced.

4. Government agencies responsible for noise control should organize regular Orientation and workshops for religious leaders and their workers

\section{References}

[1] Barbosa ASM, Cardoso MRA (2005). Hearing loss among workers exposed to road traffic noise in the city of São Paulo in Brazil. Auris Nasus Larynx 32, 17-21.

[2] Bahreyni T, Pour Sadegh M, Tamjidi A, Bazri A (1997). Sound pollutants in the industrial environments of Mashhad. Med J Mashhad Univ Med Sci 40, 27-32.

[3] Ehteshmzadeh S. (1997): Workers exposure to high noise level in environment and public place. Proceedings of the 1st Scientific Congress about Noise and Its Effect on Human, Tehran, Iran. 36-36.

[4] Gerhardt KJ, Abrams R (2000). Fetal exposures to sound and vibroacoustic stimulation. J Perinatol 20, 21-30.

[5] Chad Kitundu and Agencies (2018). Nairobi News. Rwanda shuts down 700 churches for noise pollution. $1^{\text {st }}$ March, 2018.

[6] Liu EH, Tan S-M (2000). Patients' perception of sound levels in the surgical suite. J Clin Anesth 12, 298-302.

[7] Way TJ, Long A, Weihing J, Ritchie R, Jones R, Bush M, Shinn JB (2013). Effect of noise on auditory processing in the operating room. J Am Coll Surg 216, 933-938.

[8] da Lilly-Tariah, Chibuike Nwosu, Victor O Ikenga, and Okechi C Mbalaso (2017) Sound Pressure Levels in Churches in Port Harcourt: A Study of Some Catholic, Anglican and Pentecostal Churches. Global journal of Otolaryngology. 9 (2): 555758.

[9] World Health Organization (2014). Occupational noise: assessing the burden of disease from work related hearing impairment at National and International levels.

[10] Atolagbe, A. M. O and Tanimowo, N. B (2006). Noise Pollution in Nigeria urban centres a focus on urban environmental sustainability: intervention and responses. Shalom publishers Akure. 77-87.

[11] Berglund B, Lindvall T (1995) Community noise. Stockholm, Sweden: World Health Organization 2 (1): 1-195.

[12] Adesanya I. O (2011). Environmental effects of Church proliferation: the Redeemed Christian church of God as a case study. International journal of humanities and social sciences, 1 (15): $177-182$.

[13] World Health Organization. (2015) A review on hearing loss due to recreational exposure to loud sound. Geneva: world health organization: 7-8.

[14] Quarteri J, Ambrosio SD, Guarnaccia C, Iannone G (2009). Experiments in room acoustics: modeling of a church sound field and reverberation time measurement. WSEAS Transactions on Signal Processing. 1-10.

[15] Asamoah- Baidoo (2011). Noise Induced Hearing loss among workers at Kotoka intl Airport M.Sc Thesis, KNUST, Kumasi. 
[16] Barbara Locher, André Piquerez, Manuel Habermacher, Martina Ragettli, Martin Röösli, Mark Brink, Christian Cajochen, Danielle Vienneau, Maria Foraster, Uwe Müller, and Jean Marc Wunderli (2018). Differences between Outdoor and Indoor Sound Levels for Open, Tilted, and Closed Windows. Int J Environ Res Public Health, 15 (1): 149.

[17] ISO/ R131 (1959), Expression of the Physical Subjective Magnitude of Sound or noise.

[18] Abdou AA. 2003) Measurement of acoustical characteristics of mosques in Saudi Arabia. J Acoust Soc Am; 113: 1505-17.
[19] National Environment (noise Standards and control) Regulations (NERD) (2003) National Environment act cap 153 .

[20] Anomohanran, O., Iwegbue, C. M. A, Oghenerhoro, I. O and Egbai, I. J. C (2008) investigation of environmental noise pollution levels of Abraka Delta State, Nigeria, Applied Science Research 3 (4): 292-297. 